\title{
Traumatic corneal flap displacement after laser in situ keratomileusis (LASIK)
}

This article was published in the following Dove Press journal:

International Medical Case Reports Journal

19 April 2017

Number of times this article has been viewed

\author{
Tsung-Han Tsai' \\ Kai-Ling Peng 1 \\ Chien-Jen Lin ${ }^{2}$ \\ 'Department of Ophthalmology, \\ ${ }^{2}$ Department of Radiology, Chi Mei \\ Medical Center, Tainan, Taiwan
}

Background: Laser in situ keratomileusis (LASIK) is the most common and popular procedure performed for the correction of refractive errors in the last two decades. We report a case of traumatic flap displacement with flap folding which occurred 3 years after LASIK was performed. Previous literature suggests that vision prognosis would be closely related to proper and prompt management of traumatic flap displacement with flap folding 3 years after LASIK. Case presentation: A 23-year-old female presented to our hospital who had undergone uneventful LASIK in both eyes 3 years prior. Unfortunately, she had suffered a blunt trauma in her right eye in a car accident. A late onset of corneal flap displacement was found with upper and lower portion of the flap being folded inside the corneal bed. Surgical intervention for debridement with subsequent reposition of corneal flap was performed as soon as possible in the operating room. A bandage contact lens was placed, and topical antibiotic and corticosteroids were given postoperatively. Two days after the operation, the displaced corneal flap was found to be well attached smoothly on the corneal bed without folds. The best-corrected visual acuity was $6 / 6$ with refraction of $-0.75 \mathrm{D}$ to $1.0 \mathrm{D} \times 175^{\circ}$ in her right eye 1 month later.

Literature review: We reviewed a total of 19 published cases of late-onset traumatic flap dislocations or displacements after LASIK with complete data from 2000 to 2014.

Conclusion: Traumatic displacement of corneal flaps after LASIK may occur after blunt injury with specific direction of force to the flap margin, especially tangential one. According to the previous literature, late-onset traumatic flap displacement may happen at any time after LASIK and be caused by various types of injuries. Fortunately, good visual function could mostly be restored with immediate and proper management.

Keywords: traumatic flap displacement, laser in situ keratomileusis, LASIK, corneal flap, reposition, debridement

\section{Introduction}

Traumatic flap displacement, which is known as one of the complications of LASIK, may occur in the early or late postoperative period. The procedures of LASIK, used worldwide to correct a wide range of refractive errors, include creating a corneal flap, lifting it, ablating the stromal bed by excimer laser and repositioning the corneal flap at the end. However, the wound healing between corneal flap and stromal bed should be diminished to maintain corneal transparency, which leads to weak flap adhesion. Lamellar wound healing is confined to the flap margin without suture to avoid astigmatism. ${ }^{1}$ Since central wound healing does not increase over time, risks of flap displacement or dislocation could be expected after face trauma.

Postoperative flap dislocation happens within the first 24 hours after surgery in approximately $1 \%-2 \%$ of patients, mostly due to eye-rubbing or eyelid motion such

143 
as squeezing or blinking. ${ }^{2,3}$ In comparison to the early-onset flap dislocation, late traumatic flap dislocation arises more than 1 week after the surgery. The increasing incidence of late traumatic flap dislocation in recent years may be related to the popularity that LASIK has gained in the last two decades, which is performed by using either microkeratome or femtosecond laser.

Here, we report a case of traumatic flap displacement after a severe car accident, in a patient who had LASIK performed 3 years prior using microkeratome. The visual outcome after appropriate surgical management was excellent. We also reviewed all previous literature published on Medline about late-onset flap dislocation and displacement after previous LASIK that required surgical reposition.

\section{Case presentation}

A 23-year-old female presented to our hospital who had undergone uneventful LASIK in both eyes 3 years prior. The patient had suffered a blunt trauma in her right eye in a severe car accident. Multiple and irregular lacerations with active bleeding in the right upper eyelid were noted in the emergency room. Our ophthalmologist was consulted for blurred vision in her right eye. Direct ophthalmoscope revealed a late-onset corneal flap displacement with the flap being folded in the superior and inferior portion. In addition, the bare stroma was exposed. The connection between the nasal hinge of the corneal flap and the cornea was still intact (Figure 1).

Surgical intervention was performed 12 hours after injury. Under an operating microscope, surface debris was thoroughly scraped by a sterile surgical sponge with continuous irrigation of BSS. The margin of the corneal flap which was still in situ was then demarcated, followed by dissection of the central portion from the stromal bed. Finally, the whole corneal flap was

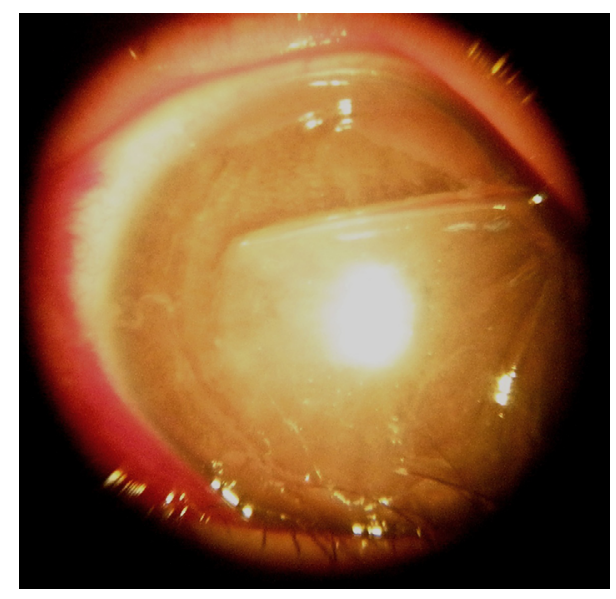

Figure I A late-onset corneal flap displacement with superior and inferior portion of flap being folded is shown. Bare stroma is exposed and intact nasal hinge is visible under surgical microscope. refloated by a LASIK spatula. To expose the whole stromal bed, the corneal flap was lifted and reflected. Meanwhile, the superior and inferior folds of corneal flap were unfolded and flattened using a sterile surgical sponge, followed by vigorous irrigation with BSS at the end. In addition, the epithelial cells and remnants adherent to the underside of the corneal flap and stromal bed were carefully removed. The corneal flap was repositioned and stretched using surgical sponges in order to avoid folds and wrinkles. At last, a bandage soft contact lens was placed on the cornea for protection (Figure 2).

Topical antibiotic ( $0.3 \%$ ciprofloxacin) and corticosteroids $(1.0 \%$ prednisolone acetate) were given postoperatively. Two days after the operation, the displaced corneal flap was found to be well attached smoothly on the stromal bed without folds and wrinkles. The bandage contact lens was removed 7 days after the operation. The best-corrected visual acuity was $6 / 6$ with refraction of $-0.75-1.0 \times 175^{\circ}$ in her right eye at 1 month. Four months later, the uncorrected vision of her right eye was 6/6 with residual refraction of $+0.25-0.25 \mathrm{D} \times 175^{\circ}$. The corneal flap was clear and smooth in situ without epithelial ingrowth (Figure 3).

Informed consent was obtained from the patient for publication of this case report and accompanying images. The ethics committee of ....... did not require written informed consent be obtained from the patient because .....

\section{Literature review}

LASIK remains the most common and popular procedure for the correction of the refractive errors. It has been increasingly used worldwide for nearly 20 years since it was approved by the US Food and Drug Administration in 1998. A new technique using femtosecond laser instead of microkeratome to make

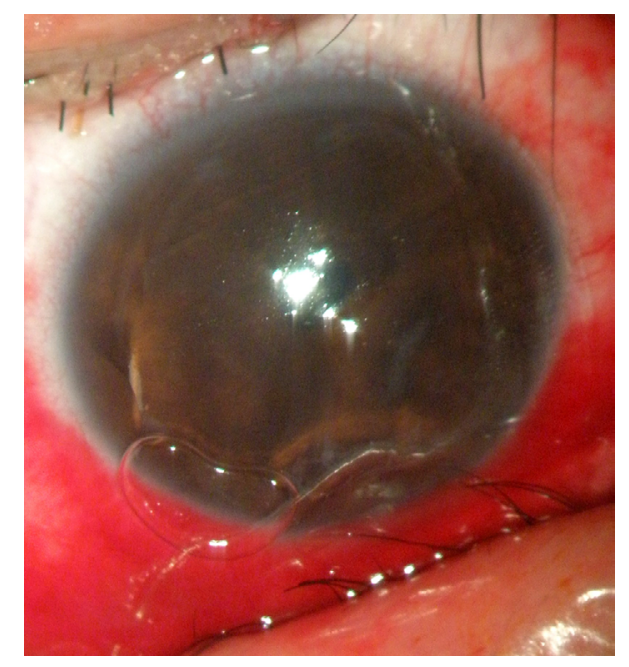

Figure 2 After reposition of the corneal flap a bandage soft contact lens is placed on the cornea for protection under surgical microscope. 


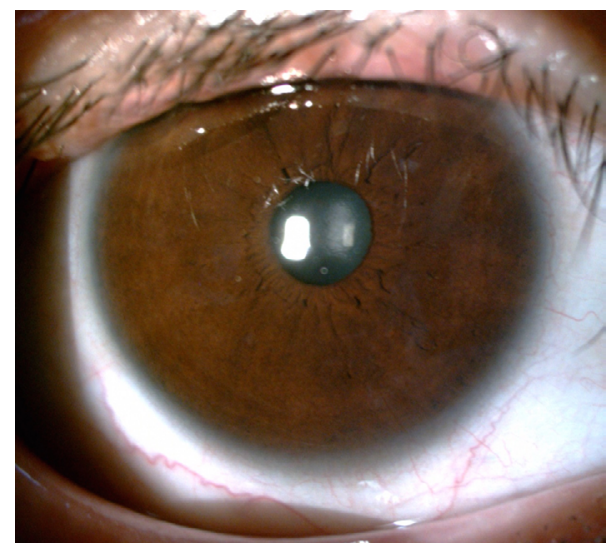

Figure 3 Four months after surgery, the corneal flap is clear and smooth in situ without epithelial ingrowth.

corneal flap has also been developed. Although less wound healing between corneal flap and stromal bed enhances corneal interface transparency, lifetime flap adhesion weakness could lead to increased risk of late traumatic flap complications. Due to our interest in the prevalence of traumatic flap displacement after LASIK, we reviewed several reports published in the previous ophthalmic literature with complete data from 2000 to 2014 on cases of late-onset traumatic flap dislocations or displacements after LASIK (Table 1). ${ }^{4-15}$ We reviewed a total of 19 cases of patients with an average age of 35 years, of whom $52.6 \%$ were male. Regarding the causes of injury, over $26 \%$ of injuries were due to sport-related activities, followed by work-related accidents (15.7\%), animal injuries (10.5\%) and failure of airbags during car accidents (10.5\%). Regarding the mechanisms of trauma, the cases of blunt trauma were more common than those of sharp trauma (Table 2).

The interval between LASIK and injury episode varied from 10 days to over 14 years, while the vision after trauma varied from counting finger to 20/20. Of all these 19 cases, patients with OTS Grade 2 accounted for $54.55 \%$ (Table 3) ${ }^{16}$ The interim between injury and surgical intervention was a maximum of 2 days. Although the uncorrected vision at last visit was generally excellent with an average of 20/25, the patients who experienced car accidents had a relatively poor average final vision of $15 / 20$. The vision prognosis of sharp injury was worse than that of blunt trauma with statistical significance (Table 2). Besides, patients with other eye injuries such as hyphema or eyelid laceration accounted for $15.7 \%$ of all 19 cases, and had ended up with a poorer average final vision of $20 / 30$. Furthermore, $31.6 \%$ of patients had developed complications even after surgical interventions, though they had an average final vision of 20/25 in the last visit. Among them, only $15.7 \%$ had undergone further treatment and ended up with an average final vision of $20 / 25$. Of all 19 cases, $94.74 \%$ of patients had ended up with an OTS Grade 1 after proper treatment (Table 3).

As for the flap condition after trauma (Table 4), flap dislocation was revealed in $73.7 \%$ of cases, which was similar to the finding of $71.1 \%$ in Xiao et al study which analyzed all the cases in the People's Republic of China. ${ }^{17}$ In our review, all the cases with corneal flap dislocation had received flap replacement (Table 5), while only $55.6 \%$ of cases in Xiao et al study had undergone the same treatment. Lack of ophthalmic doctors skilled in refractive surgery could be one possible factor. ${ }^{17}$ During flap replacement surgery, epithelial scraping had been performed to avoid epithelial ingrowth or residual debris in $63.2 \%$ of patients, which led to dissemination of lamellar keratitis at last. At the end of the surgery, up to $73.7 \%$ of patients were covered with bandage contact lens to make the folded flaps more flat and then smoothly settle on the stromal beds and remain in situ (Table 5).

\section{Discussion}

After LASIK surgery, the whole processes and exact mechanisms of wound healing at the interface of corneal flap-stromal bed and around the free margins of corneal flap remain unclear. Less and delayed wound healing at the stromal interface is believed to keep cornea transparent, leading to weaker adhesion in the central part compared to the surrounding epithelial rim margin, which was confirmed by the surgical experience during retreatment of LASIK. Schmack et al found that the wound margin of LASIK flap heals by producing peripheral hypercellular fibrotic stromal scar, which is about $28.1 \%$ as strong as normal corneal stroma. In contrast, the central and paracentral hypocellular primitive stromal scar is only $2.4 \%$ as strong as normal corneal stroma, which means it is 10 times weaker then peripheral margin scar. ${ }^{18}$ Kato et al studied corneal wound healing in an animal model. Their work on immunohistochemical staining and electron microscopy following LASIK showed that up to 9 months after the procedure, wound healing continued to be disorganized and delayed at the interface region. ${ }^{19}$

The corneal flaps have free margins about more than $270^{\circ}$ without any sutures and anchors except the hinge area, which is attached to the corneal flap smaller than $90^{\circ}$. Any shearing forces, which are tangential to the corneal flap regardless of mechanism and direction, may induce breaking of not only the loose adhesion between corneal flap and stromal bed but also the connection between the free margins and peripheral cornea. These tangential shearing forces may drag the corneal flap away from the corresponding stromal bed and peripheral cornea, leading to the dislocation/stria/split. According to the appearance of corneal flap folding and 
Table I Summary of previous literature reporting late flap dislocations or displacements after LASIK

\begin{tabular}{|c|c|c|c|c|c|c|}
\hline $\begin{array}{l}\text { Case } \\
\text { number }\end{array}$ & Reference & Age/gender & Mechanism of injury & $\begin{array}{l}\text { Injury time } \\
\text { after LASIK }\end{array}$ & $\begin{array}{l}\text { VA after } \\
\text { trauma }\end{array}$ & Flap condition after trauma \\
\hline 1 & Sinha et $\mathrm{al}^{4}$ & $26 / F$ & Wooden splinter & 4 years & $20 / 60$ & $\begin{array}{l}\text { Dislocation, infolding, macrostriae, } \\
\text { epithelial ingrowth }\end{array}$ \\
\hline 2 & Esteban et $a^{5}$ & 29/M & Screwdriver & 10 years & Nil & Dislocation, inverted corneal flap tear \\
\hline 3 & Khoueir et $\mathrm{al}^{6}$ & Nil & Recreational activities & 10 years & Nil & Dislocated \\
\hline 4 & Holt et $\mathrm{al}^{7}$ & $59 / N R$ & Blunt trauma & 14 years & Nil & $\begin{array}{l}\text { Dislocation, epithelial ingrowth, } \\
\text { significant macrostriae }\end{array}$ \\
\hline 5 & Tai et $\mathrm{al}^{8}$ & $34 / M$ & Struck with a basketball & I years & Nil & Nil \\
\hline 6 & Tai et $\mathrm{al}^{8}$ & $27 / M$ & $\begin{array}{l}\text { "Finger-flick" in } \\
\text { sporting }\end{array}$ & I year & $\mathrm{CF}$ & $\begin{array}{l}\text { Total dislocated, corneal flap, } 100 \% \\
\text { exposed bed }\end{array}$ \\
\hline 7 & Tumbocon et $\mathrm{al}^{9}$ & $25 / M$ & Struck by a dog's paw & 26 months & $20 / 25$ & Dislocation, flap folding and striae \\
\hline 8 & Tumbocon et al ${ }^{9}$ & $35 / M$ & Struck a rock & 7 months & $\mathrm{CF}$ at I $\mathrm{m}$ & Dislocation \\
\hline 9 & Aldave et al ${ }^{10}$ & 29/M & $\begin{array}{l}\text { Struck with a finger } \\
\text { while playing basketball }\end{array}$ & 18 months & $20 / 200$ & Dislocation, exposed stromal bed \\
\hline 10 & Sridhar et al"I & $35 / F$ & Self removal with SCL & 10 days & $20 / 70$ & Loss of the flap \\
\hline 11 & $\begin{array}{l}\text { Lombardo and } \\
\text { Katz }^{12}\end{array}$ & $43 / F$ & Asymptomatic & 4 months & $20 / 60$ & Dislocation, flap wrinkled \\
\hline 12 & Iskander et al $\left.\right|^{13}$ & $5 \mathrm{I} / \mathrm{F}$ & $\begin{array}{l}\text { Pecan falling from a } \\
\text { tree }\end{array}$ & 3 months & $20 / 70$ & Flap folding \\
\hline 13 & Iskander et $\mathrm{al}^{13}$ & $32 / M$ & Hit with a cable & 3 months & $\mathrm{Nil}$ & Dislocation, microfolds, gutter \\
\hline 14 & Iskander et al ${ }^{13}$ & $20 / F$ & Airbag deployed & 38 months & $20 / 20$ & Dislocation, flap wrinkling \\
\hline 15 & Melki et al ${ }^{14}$ & $28 / M$ & Basketball & 10 days & Nil & Dislocation, flap tear, flap folding \\
\hline 16 & Melki et al ${ }^{14}$ & $2 I / M$ & Finger & 24 days & Nil & $\begin{array}{l}\text { Dislocation, flap folding, epithelial } \\
\text { ingrowth }\end{array}$ \\
\hline 17 & Melki et al ${ }^{14}$ & $61 / F$ & Dog's paw & 6 weeks & Nil & Dislocation, exposed stromal bed \\
\hline 18 & Melki et al ${ }^{14}$ & $38 / M$ & Snowball & 2 months & $20 / 60$ & $\begin{array}{l}\text { Dislocation, edema, exposed stromal } \\
\text { bed }\end{array}$ \\
\hline 19 & Lemley et $\mathrm{al}^{15}$ & $37 / F$ & Airbag deployment & 17 months & Nil & Corneal abrasions, dislocation \\
\hline
\end{tabular}

Notes: (-) indicates no second surgery; (+) indicates yes.

Abbreviations: CF, counting fingers; LASIK, laser in situ keratomileusis; NR, not reported; SCL, soft contact lens; VA, visual acuity; UCVA, uncorrected visual acuity.

Table 2 Vision prognosis and average age according to mechanisms of injury

\begin{tabular}{llll}
\hline & Sharp trauma & Blunt trauma & P value \\
\hline $\begin{array}{l}\text { Percentage of different } \\
\text { mechanisms of injures }\end{array}$ & 31.58 & 52.63 & \\
Average age (years) & 31.50 & 35.70 & 0.5676 \\
Log $_{\text {UCVA }}$ & -0.0162 & -0.0954 & 0.0495 \\
\hline
\end{tabular}

Abbreviation: UCVA, uncorrected visual acuity.

stria, the direction of shearing forces could be speculated. The pictures of the corneal flap dislocation in our patient showed a larger upper portion of the corneal flap compared to the lower portion. Furthermore, there was a part of the upper portion cornea folding between the stromal bed and cornea itself. Besides, the patient had multiple lacerations over upper eyelids. These are all hints that the strong shearing forces came from up to down. Femtosecond laser-assisted
Table 3 Percentage of vision after trauma and after treatment according to OTS

\begin{tabular}{lll}
\hline & After LASIK and trauma (\%) & After treatment (\%) \\
\hline OTS Grade I & 18.18 & 94.74 \\
OTS Grade 2 & 54.55 & 5.26 \\
OTS Grade 3 & 27.27 & 0.00 \\
\hline
\end{tabular}

Note: Grade I: $\geq 20 / 40$; Grade 2: 20/200-20/50; and Grade 3: 1/200-19/200. Abbreviations: OTS, ocular trauma score, LASIK, laser in situ keratomileusis.

Table 4 Percentage of cases with respect to corneal flap conditions after trauma

\begin{tabular}{ll}
\hline Flap condition & Case (\%) \\
\hline Flap dislocation (with or without striae or fold) & 73.7 \\
Flap folds or striae without flap dislocation & 15.8 \\
Isolated severe flap edema & 10.5 \\
Isolated epithelial ingrowth & 15.8 \\
Loss of flap & 5.3 \\
Flap tear with or without part loss & 10.5 \\
\hline
\end{tabular}


Table I (Continued)

\begin{tabular}{|c|c|c|c|c|c|c|}
\hline Other eye injuries & $\begin{array}{l}\text { Time of } \\
\text { intervention }\end{array}$ & Intervention & $\begin{array}{l}\text { Complication after } \\
\text { intervention }\end{array}$ & $\begin{array}{l}\text { Time of full } \\
\text { recovery }\end{array}$ & $\begin{array}{l}\text { UCVA of } \\
\text { last visit }\end{array}$ & Enhancement \\
\hline Nil & Nil & Reposition, debridement & Nil & 12 days & $20 / 20$ & $(-)$ \\
\hline Nil & Nil & Reposition, soft contact lens & Epithelial ingrowth & Nil & Nil & $(-)$ \\
\hline $\mathrm{Nil}$ & Nil & $\mathrm{Nil}$ & Nil & Nil & $20 / 20$ & $(-)$ \\
\hline Nil & Nil & Reposition, debridement & Nil & 35 days & $20 / 30$ & $(-)$ \\
\hline Nil & Nil & $\begin{array}{l}\text { Reposition, debridement, soft } \\
\text { contact lens, antibiotics, steroid }\end{array}$ & Nil & Nil & $20 / 20$ & $(-)$ \\
\hline Nil & Nil & $\begin{array}{l}\text { Reposition, debridement, soft } \\
\text { contact lens, antibiotics, steroid }\end{array}$ & Nil & Nil & $20 / 20$ & $(-)$ \\
\hline Nil & 4 hours & $\begin{array}{l}\text { Reposition, debridement, soft } \\
\text { contact lens }\end{array}$ & $\begin{array}{l}\text { Grade I diffuse lamellar } \\
\text { keratitis }\end{array}$ & 5 days & $20 / 20$ & (+) 3 months \\
\hline $\begin{array}{l}\text { Lid laceration, } \\
\text { periorbital edema, } \\
\text { orbital floor fracture }\end{array}$ & 2 days & Reposition & $\begin{array}{l}\text { Striae crossing the visual } \\
\text { axis }\end{array}$ & 17 days & $20 / 40$ & $(-)$ \\
\hline Nil & I hour & Reposition, soft contact lens & $\begin{array}{l}\text { Epithelial } \\
\text { ingrowth }\end{array}$ & I day & $20 / 25$ & (+) 4 months \\
\hline Nil & Immediately & Soft contact lens & Nil & 10 days & $20 / 70$ & $(-)$ \\
\hline Nil & Immediately & Reposition, soft contact lens & Nil & 20 days & $20 / 25$ & (+) 4 months \\
\hline $\begin{array}{l}\text { I+ anterior chamber } \\
\text { cells }\end{array}$ & 48 hours & Reposition, debridement & Epithelial ingrowth & I week & $20 / 20$ & $(-)$ \\
\hline Nil & Few hours & Reposition, debridement & Minimal fibrosis & Nil & $20 / 20$ & $(-)$ \\
\hline Nil & Immediately & Reposition & Nil & Nil & $20 / 20$ & $(-)$ \\
\hline Nil & $<6$ hours & $\begin{array}{l}\text { Reposition, soft contact lens, } \\
\text { topical antibiotics, steroids }\end{array}$ & Nil & 2 months & $20 / 30$ & $(-)$ \\
\hline Nil & 12 hours & $\begin{array}{l}\text { Reposition, debridement, soft } \\
\text { contact lens, topical antibiotics, } \\
\text { steroids }\end{array}$ & Nil & I week & $20 / 20$ & $(-)$ \\
\hline Nil & $<6$ hours & $\begin{array}{l}\text { Reposition, debridement, soft } \\
\text { contact lens, topical antibiotics, } \\
\text { steroid }\end{array}$ & Nil & 5 weeks & $20 / 21$ & $(-)$ \\
\hline Nil & $<6$ hours & $\begin{array}{l}\text { Reposition, debridement, soft } \\
\text { contact lens, topical antibiotics, } \\
\text { steroid }\end{array}$ & Nil & 2 weeks & $20 / 20$ & $(-)$ \\
\hline Hyphema & Immediately & Reposition & Epithelial ingrowth & 8 months & $20 / 40$ & $(-)$ \\
\hline
\end{tabular}

Table 5 Percentage of cases which received treatments after trauma

\begin{tabular}{ll}
\hline Treatment & Case (\%) \\
\hline Flap replacement & 100.0 \\
Epithelial scrape & 63.2 \\
Isolated eye drops & 36.8 \\
Conjunctival laceration suture & 5.3 \\
Bandage contact lens & 73.7 \\
Epithelial removal & 5.3 \\
\hline
\end{tabular}

LASIK also involves a corneal flap, which may have risks of late-onset traumatic flap dislocation if the force causing blunt trauma comes from a proper angle. However, there are no available studies comparing the late complications of these two different methods of LASIK. Contrary to the LASIK, SMILE, the newest refractive surgery, involves smaller degrees of free margins and cap incision despite the same interface between the corneal cap and stromal beds. We deduced that even shearing forces can cause breaking of the loose adhesion between corneal cap and stromal bed, and the counterforce of cornea with non-free margin could resist the force, therefore preventing the corneal cap from moving. However, further studies and mechanical models are required to prove that SMILE might cause less complication after trauma.

Because the corneal flaps never heal after LASIK, eye protection should be used before participating in dangerous sports such as basketball and also in work such as gardening. Once traumatic accidents occur, careful and detailed examinations should be undertaken under slit lamp as soon as possible. If dislocation/stria/split of corneal flaps is identified 
during emergent conditions, corneal flap reposition should be considered immediately. Thorough irrigation and scraping off the debris by sponges between corneal flaps and stromal beds should not be ignored. Soft bandage contact lens should be placed at the end of surgeries. Previous experiences suggest that the vision prognosis would be good if proper managements and treatments are followed.

\section{Abbreviations}

BSS, balanced salt solution; LASIK, laser in situ keratomileusis; OTS, ocular trauma score; SMILE, SMall Incision Lenticule Extraction.

\section{Disclosure}

The authors report no conflicts of interest in this work.

\section{References}

1. Ursea R, Feng MT. Truamtic flap striae 6 years after LASIK: case report and literature review. J Refract Surg. 2010;26(11):899-905.

2. Lin RT, Maloney RK. Flap complications associated with lamellar refractive surgery. Am J Ophthalmol. 1999;127(2):129-136.

3. Stulting RD, Carr JD, Thompson KP, Waring GO 3rd, Wiley WM, Walker JG. Complications of laser in situ keratomileusis for the correction of myopia. Ophthalmology. 1999;106(1):13-20.

4. Sinha R, Shekhar H, Tinwala S, Gangar A, Titiyal JS. Late post-traumatic flap dislocation and macrostriae after laser in situ keratomileusis. Oman J Ophthalmol. 2014;7(1):25-27.

5. Esteban O, Rodriguez NA, Ascaso FJ, Solanas S. Role of SD-OCT in the diagnosis and management of a late-onset corneal LASIK flap tear secondary to screwdriver trauma. Acta Ophthalmologica. 2014;92(s253).

6. Khoueir Z, Haddad NM, Saad A, Chelala E, Warrak E. Traumatic flap dislocation 10 years after LASIK. Case report and literature review. J Fr Ophtalmol. 2013;36(1):82-86.
7. Holt DG, Sikder S, Mifflin MD. Surgical management of traumatic LASIK flap dislocation with macrostriae and epithelial ingrowth 14 years postoperatively. $J$ Cataract Refract Surg. 2012;38(2):357-361.

8. Tai MC, Chen $\mathrm{CH}$, Chang CJ. Late traumatic dislocation of LASIK corneal flaps. J Med Sci. 2003;23(3):165-166.

9. Tumbocon JA, Paul R, Slomovic A, Rootman DS. Late traumatic displacement of laser in situ keratomileusis flaps. Cornea. 2003;22(1): 66-69.

10. Aldave AJ, Hollander DA, Abbott RL. Late-onset traumatic flap dislocation and diffuse lamellar inflammation after laser in situ keratomileusis. Cornea. 2002;21(6):604-607.

11. Sridhar MS, Rapuano CJ, Cohen EJ. Accidental self-removal of a flap-a rare complication of laser in situ keratomileusis surgery. $\mathrm{Am} \mathrm{J}$ Ophthalmol. 2001;132(5):780-782.

12. Lombardo AJ, Katz HR. Late partial dislocation of a laser in situ keratomileusis flap. J Cataract Refract Surg. 2001;27(7):1108-1110.

13. Iskander NG, Peters NT, Anderson Penno E, Gimbel HV. Late traumatic flap dislocation after laser in situ keratomileusis. $J$ Cataract Refract Surg. 2001;27(7):1111-1114.

14. Melki SA, Talamo JH, Demetriades AM, et al. Late traumatic dislocation of laser in situ keratomileusis corneal flaps. Ophthalmology. 2000; 107(12):2136-2139.

15. Lemley HL, Chodosh J, Wolf TC, Bogie CP, Hawkins TC. Partial dislocation of laser in situ keratomileusis flap by air bag injury. $J$ Refract Surg. 2000;16(3):373-374.

16. Kuhn F, Maisiak R, Mann L, Mester V, Morris R, Witherspoon CD. The Ocular Trauma Score (OTS). Ophthalmol Clin North Am. 2002;15(2): $163-165$, vi.

17. Xiao J, Jiang C, Zhang M, Jiang H, Li S, Zhang Y. When case report became case series: 45 cases of late traumatic flap complications after laser-assisted in situ keratomileusis and review of Chinese literature. Br J Ophthalmol. 2014;98(9):1282-1286.

18. Schmack I, Dawson DG, McCarey BE, Waring GO 3rd, Grossniklaus HE, Edelhauser HF. Cohesive tensile strength of human LASIK wounds with histologic, ultrastructural, and clinical correlations. J Refract Surg. 2005;21(5):433-445.

19. Kato T, Nakayasu K, Hosoda Y, Watanabe Y, Kanai A. Corneal wound healing following laser in situ keratomileusis (LASIK): a histopathological study in rabbits. Br J Ophthalmol. 1999;83(11):1302-1305.
International Medical Case Reports Journal

\section{Publish your work in this journal}

The International Medical Case Reports Journal is an international, peer-reviewed open-access journal publishing original case reports from all medical specialties. Previously unpublished medical posters are also accepted relating to any area of clinical or preclinical science. Submissions should not normally exceed 2,000 words or

\section{Dovepress}

4 published pages including figures, diagrams and references. The manuscript management system is completely online and includes a very quick and fair peer-review system, which is all easy to use. Visit http://www.dovepress.com/testimonials.php to read real quotes from published authors. 